\title{
Experimental infection of human nasal mucosal explants with Neisseria meningitidis
}

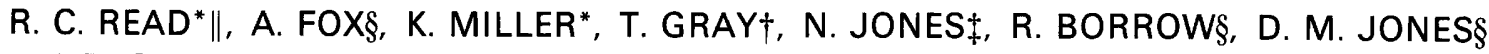 \\ and R. G. FINCH* \\ * Departments of Microbial Diseases and Pathology, City Hospital, University of Nottingham, Departments of \\ $\dagger$ Pathology and $\ddagger$ Surgery, University Hospital, Nottingham and $\S$ Manchester Public Health Laboratory, Withington \\ Hospital, Manchester
}

\begin{abstract}
Summary. The interaction of Neisseria meningitidis with rhinopharyngeal epithelium was studied by experimental infection of explants of human nasal turbinate mucosa with two wild strains: a fully capsulate case isolate, and an epidemiologically related non-capsulate nasopharyngeal isolate. After incubation for $4 \mathrm{~h}$, epithelial cells of infected explants changed conformation from tall columnar morphology towards cuboidal, and there was increased discharge of mucus globules from goblet cells. By $24 \mathrm{~h}$ there was significant damage to infected epithelia, including projection of cells out of the surface, cytoplasmic blebbing and mitochondrial abnormalities. Meningococci were associated with surface non-ciliated cells by $4 \mathrm{~h}$ after infection. By $24 \mathrm{~h}$ after infection they were associated extensively with all cell types exhibiting damage. There was little association with secreted mucus. In areas of cell damage, penetration between surface cells was observed. Endocytosis into non-ciliated cells was observed in only a minority of explants studied and only in those infected for $24 \mathrm{~h}$. From this intracellular site there was apparent migration to adjacent cells and to intercellular locations. No organisms were observed within or beneath basement membrane collagen in any explants but internalisation into mononuclear phagocytes was observed occasionally.
\end{abstract}

\section{Introduction}

The human upper respiratory tract is the only natural habitat of Neisseria meningitidis which occasionally causes invasive disease, including meningitis. Colonisation of the nasopharynx is probably the initial step in the pathogenesis of systemic disease; supporting evidence for this is the correlation between the prevalence of community carriage and of the occurrence of disease due to group A meningococci. ${ }^{1}$ During non-epidemic periods, the baseline prevalence of nasopharyngeal carriage of meningococci is $5-10 \%$ but can be $50-80 \%$ in certain circumstances, such as military dormitories. ${ }^{2}$ Factors affecting carriage include close contact, and also age, sex and tobacco smoke. ${ }^{3}$ During natural carriage the organism can be isolated both from the rhinopharynx and from the throat. ${ }^{4}$

Studies with explants of human adenoid mucosa

Received 28 Oct. 1994; accepted 29 Nov. 1994.

II Present address and address for correspondence: Department of Medical Microbiology, University of Sheffield Medical School, Beech Hill Road, Sheffield S10 2JF. and cultured epithelial monolayers have provided insights into the biological process of meningococcal colonisation. In vitro, the meningococcus attaches to epithelial cells via adhesins including pili ${ }^{5}$ and class $5 \mathrm{C}$ opacity proteins ${ }^{6}$ and is able to enter non-ciliated cells of adenoid mucosa by a process that resembles parasite-directed endocytosis. ${ }^{7-9}$ The subsequent progress of meningococci is unclear, but they have been observed within the subepithelium of adenoid organ cultures adjacent to lymphoid follicles after infection for $24 \mathrm{~h}$ in vitro. ${ }^{7}$ There is currently no direct evidence that epithelial attachment and endocytosis occur during natural colonisation of the upper respiratory tract. Nonetheless, these processes are potentially important both in colonisation and invasion.

The present study used a previously described model of bacterial interaction with ciliated human turbinate mucosa in which only the epithelial surface is exposed and in which the potential influence of antibiotics is kept to a minimum. ${ }^{10}$ Light microscopy and scanning electronmicroscopy were used to observe surface events occurring during infection of the organ culture, and transmission electronmicroscopy (TEM) was used to quantify epithelial cell damage, bacterial association 
with the surface, and bacterial endocytosis. The purpose of the study was to elucidate gross mechanisms by which meningococci might achieve stable colonisation of the rhinopharynx which, in contrast to the adenoid mucosa, is lined by richly ciliated epithelium..$^{11}$ Two natural isolates from a 1986 outbreak of meningitis in Gloucestershire were employed. The two strains K454 and SH1497 have been described previously and shown to be virulent and avirulent, respectively, following intranasal inoculation of infant mice. ${ }^{12}$

\section{Materials and methods}

\section{Bacteria}

Systemic capsulate case isolates and epidemiologically related non-groupable isolates from the nasopharynx of asymptomatic carriers were obtained during an epidemiological investigation into an outbreak of meningococcal disease in the Gloucestershire Health District of the UK. ${ }^{13}$ Organisms were serotyped, subtyped and lipo-oligosaccharide immunotyped by dot blotting with type specific monoclonal antibodies as described previously. ${ }^{14}$ Strains K454 (B15 P1.7, 16 L3, 7, 9, sulphonamide resistant) and SH1497 (NG15. P1.7, 16 L3, 7, 9, sulphonamide resistant) were identified as capsulate (groupable) and non-capsulate (non-groupable), respectively, by agglutination with rabbit polyclonal antisera to meningococcal capsular polysaccharide. Capsule expression was quantified by whole cell ELISA ${ }^{15}$ and expressed as the percentage of the mean $\mathrm{OD}_{640 \mathrm{~nm}}$ for six unrelated serogroup B case isolates. Both strains displayed pili on negative stain transmission electronmicroscopy. Strains were stored on glass beads at $-70^{\circ} \mathrm{C}$ and were plated out overnight on to lysed blood agar before inoculation into the organ culture model. From these plates, two colonies were touched with a loop, transferred to $5 \mathrm{ml}$ of Mueller Hinton broth in a 6-ml screwcapped bottle, and incubated to mid log phase for $4 \mathrm{~h}$ at $37^{\circ} \mathrm{C}$ on a rolling stage. Broth culture $(1 \mathrm{ml})$ was centrifuged at $2000 \mathrm{~g}$, washed, and centrifuged three times with $1 \mathrm{ml}$ of PBS. Twenty $\mu \mathrm{l}$ of the final wash were inoculated into $3 \mathrm{ml}$ of Minimal Essential Medium (MEM; Gibco, Uxbridge) to produce a final suspension containing $c .10^{5} \mathrm{cfu} / \mathrm{ml}$ of test strains.

\section{Organ culture of nasopharyngeal mucosa}

This model system has been described previously. ${ }^{10}$ Briefly, inferior turbinates resected from patients with non-allergic nasal obstruction were transported to the laboratory in MEM supplemented with penicillin (50 units $/ \mathrm{ml})$, streptomycin $(50 \mathrm{mg} / \mathrm{L}$ ) and gentamicin $(50 \mathrm{mg} / \mathrm{L})$ and dissected to produce 3-4-mm squares of mucosa. Tissue was then immersed in $20 \mathrm{ml}$ of antibiotic-free MEM for $1 \mathrm{~h}$ before being placed, cut surface downwards, on to molten agar (No. 1, Oxoid) at $40^{\circ} \mathrm{C}$, coating the bottom of a 4-cm petri dish. This agar sets as it cools to $37^{\circ} \mathrm{C}$. Agar was pipetted around the tissue edge to ensure full occlusion of cut surfaces; once the agar had solidified MEM (without antibiotics) was added. Organ cultures were then inspected by light microscopy; any explants that did not exhibit ciliary activity over the entire length of at least one tissue edge were discarded. Suitable organ cultures were incubated for a further hour, whereupon MEM was replaced by $3 \mathrm{ml}$ of MEM with or without $20 \mu \mathrm{l}$ of the test strain suspended in PBS. The culture was then incubated for $24 \mathrm{~h}$ in a humidified atmosphere of $\mathrm{CO}_{2}$ $5 \%$ in air at $37^{\circ} \mathrm{C}$. Organ cultures were examined at $\times 32$ magnification by light microscopy at intervals during this period. Viable counts of $N$. meningitidis in the supernate were made at intervals by a standard dilution and plate count technique. Any explants infected with organisms other than $N$. meningitidis were discarded along with their controls and were not examined further. The inoculum and organisms recovered sequentially during the time course of organ culture experiments were re-examined for phenotype as described above.

\section{Transmission electronmicroscopy and morphometric analysis}

Tissue was fixed in cacodylate-buffered glutaraldehyde $2.5 \%$ and post-fixed in osmium tetroxide $1 \%$. Tissue was then dehydrated and embedded in araldite by standard techniques. A randomly selected ultrathin section through the central part of each specimen was examined. Sections typically consisted of 50-100 cells. Each cell in a section was scored from 1 to 5 for four parameters of damage: projection of cells from the surface, loss of cilia, cytoplasmic blebbing and mitochondrial abnormalities. This method of morphometric analysis has been described previously in detail. ${ }^{10} \mathrm{~A}$ mean damage score for each parameter was calculated by dividing the sum of the scores by the number of cells counted. Mucin-containing nonciliated cells were distinguished by the presence of amorphous mucinous material within cells. To further assess changes in cell morphology, the length:width ratio of surface epithelial cells was calculated with a graticule to examine one cell chosen at random from the centre of each grid in a section, and a mean value was expressed. Goblet cells that had discharged their mucus were identified by the appearance of a scooped out luminal surface and depleted numbers of secretory granules adjacent to the luminal membrane.

When $N$. meningitidis cells were seen in the section, the frequency of association of bacteria with ciliated and non-ciliated cells was expressed as the percentage of cells associating with $N$. meningitidis within a single cell diameter above the surface (i.e. $10-30 \mu \mathrm{m}$ ). The distinction was made between association and adherence because a bacterium in proximity to (but not touching) a cell in one ultrathin section may be seen to be attached to that cell in adjacent sections; the 
arbitrary distance of 10-30 $\mu \mathrm{m}$ was chosen to allow for changes in epithelial surface contour. Where polymorphonuclear leucocytes were identified above the basement membrane, their number was expressed per grid square. Where $N$. meningitidis cells were seen within membrane-bound intracellular vesicles, the frequency of internalisation was calculated as a percentage of the total number of ciliated or non-ciliated cells in a section. When $N$. meningitidis cells were seen associating with basal cells in deep intracellular locations, their presence was noted.

\section{Scanning electronmicroscopy (SEM)}

The explant was fixed in glutaraldehyde $2.5 \%(0.5 \mathrm{M}$ sodium cacodylate buffer at $\mathrm{pH} 7 \cdot 2)$ for a minimum of $24 \mathrm{~h}$ before routine processing through gentle buffer washes, osmium tetroxide $1 \%$ (in identical buffer) for $1 \mathrm{~h}$, dehydration through graded ethanols to acetone and critical point drying in $\mathrm{CO}_{2}$. Tissue was mounted on aluminium stubs, sputter-coated with gold and examined at $25 \mathrm{kV}$ in a JEOL 35 scanning electronmicroscope.

\section{Protocol}

Organ cultures were initiated in which bacterial growth and explant morphology (by light microscopy, histology of $1-\mu \mathrm{m}$ sections and TEM) were examined after incubation with the two strains for $24 \mathrm{~h}(\mathrm{n}=9)$. For each individual experiment, tissue from a separate human source was used, and a control explant was included. For each strain, one experiment was performed in which control and infected tissue were incubated and examined by light microscopy, TEM and SEM after $30 \mathrm{~min}, 4,14$ and $24 \mathrm{~h}$. After analysis of this, a further series of experiments was performed in which organ cultures were infected with each of the two strains for $4 \mathrm{~h}(\mathrm{n}=7)$.

\section{Statistical analysis}

For morphometric analysis of epithelial cell damage, comparisons between control and infected explants were made by Kruskal-Wallis analysis. Where the null hypothesis was rejected, statistical significance of differences was assessed by the MannWhitney test. Comparisons between epithelial association of the two strains were assessed by $\chi^{2}$ analysis (with Yates's correction). For all analyses, $\mathrm{p}<0.05$ was considered significant.

\section{Results}

By light microscopy, control explants remained apparently normal after incubation for $24 \mathrm{~h}$. The $\mathrm{pH}$ of control and infected supernates was 7-8 after incubation for $24 \mathrm{~h}$. In the series of experiments in which explants were infected for $4 \mathrm{~h}$, strain K454 replicated from an initial inoculum of 6.36 (SEM $1.45) \times 10^{5} \mathrm{cfu} / \mathrm{ml}$ to $1.84(\mathrm{SEM} 1.30) \times 10^{8} \mathrm{cfu} / \mathrm{ml}$; strain SH1497 replicated from 4.88 (SEM $2.65) \times 10^{5} \mathrm{cfu} / \mathrm{ml}$ to $1.35($ SEM 0.68$) \times 10^{8} \mathrm{cfu} / \mathrm{ml}$ $(\mathrm{n}=7)$. In the series in which explants were infected for $24 \mathrm{~h}$, strain K454 replicated from 1.05 (SEM $0.46) \times 10^{5} \mathrm{cfu} / \mathrm{ml}$ to $4.36($ SEM 1.48$) \times 10^{8} \mathrm{cfu} / \mathrm{ml}$, and strain SH1497 from 0.96 (SEM 0.45) $\times 10^{5} \mathrm{cfu} / \mathrm{ml}$ to $1.49(\mathrm{SEM} 1 \cdot 26) \times 10^{8} \mathrm{cfu} / \mathrm{ml}(\mathrm{n}=9)$. There were no significant differences in the rate of replication between strains. Capsule expression for strain K454 and for strain SH1497 quantified by whole cell ELISA was found to be $108 \%$ and $1 \%$, respectively. Organisms present in the inoculum and recovered sequentially from infected organ cultures over the experimental period were unchanged and remained true to their original phenotype. No revertants for capsular phenotype were identified.

The findings on explant microscopy are described below.

Infection with N. meningitidis: epithelial damage and mucus discharge

By light microscopy, control explants maintained normal structure and active ciliary beating over $24 \mathrm{~h}$. In infected explants, both strains caused accumulation of mucus, debris and extruded epithelial cells within the supernate of infected explants that was maximal by $24 \mathrm{~h}$.

Histological studies showed that epithelial cells of control explants remained predominantly ciliated and retained tall columnar conformation until $24 \mathrm{~h}$ when they appeared more cuboidal. Examination of serial $1-\mu \mathrm{m}$ sections of explants infected for $30 \mathrm{mins}, 4 \mathrm{~h}$, $14 \mathrm{~h}$ and $24 \mathrm{~h}$ revealed gradual widespread (not patchy) loss of integrity of the epithelium.

Analysis of transmission electronmicrographs (TEM) of the series of explants infected for $4 h(n=7)$ revealed reductions in the length: width ratio of surface epithelial cells and an increase in the percentage of cells identified as goblet cells that had discharged their mucus (table I). There was no significant projection of cells from the surface, loss of cilia from ciliated cells, cytoplasmic blebbing or mitochondrial abnormalities compared to controls (table II). Morphometric analysis of TEM of explants infected for $24 \mathrm{~h}(\mathrm{n}=9)$ revealed damage of equivalent explants infected by strain K454 and strain SH1497 (table II). Mean damage scores for infected tissue were significantly greater than for uninfected controls and reflected excesses of cells projecting out of the surface, cytoplasmic blebbing and mitochondrial abnormalities of epithelial cells. After $24 \mathrm{~h}$, discharged goblet cells could not be accurately distinguished from other dead or disrupted cells. There was no difference in the number of polymorphonuclear leucocytes above the basement membrane of infected explants compared to 
Table I. TEM features of control explants and explants infected with two strains of $N$. meningitidis for $4 \mathrm{~h}$ or $24 \mathrm{~h}$

\begin{tabular}{|c|c|c|c|c|c|}
\hline $\begin{array}{l}\text { Explant } \\
\text { culture }\end{array}$ & $\begin{array}{l}\text { Cells/ } \\
\text { section }\end{array}$ & $\begin{array}{l}\text { Ciliated } \\
\text { cells }(\%)\end{array}$ & $\begin{array}{l}\text { Mucin- } \\
\text { containing } \\
\text { cells } \\
(\%)\end{array}$ & $\begin{array}{c}\text { Discharged } \\
\text { goblet } \\
\text { cells } \\
(\%)\end{array}$ & $\begin{array}{l}\text { Length: } \\
\text { width ratio }\end{array}$ \\
\hline \multicolumn{6}{|l|}{$4 \mathrm{~h}(\mathrm{n}=7)$} \\
\hline Control & $107 \cdot 3(16.9)$ & $61.9(11.6)$ & $18 \cdot 3(4 \cdot 1)$ & $17 \cdot 7(8 \cdot 2)$ & $8.7(0.4)$ \\
\hline SH1497 & $92 \cdot 3(24 \cdot 6)$ & $54 \cdot 3(6.4)$ & $24 \cdot 1(3 \cdot 5)$ & $32 \cdot 0(5 \cdot 3)^{*}$ & $4 \cdot 2(1 \cdot 3)^{*}$ \\
\hline $\mathrm{K} 454$ & $90.6(15 \cdot 7)$ & $55.4(10.9)$ & $27 \cdot 0(4 \cdot 8)$ & $32 \cdot 1(5 \cdot 1)^{*}$ & $5 \cdot 1(1 \cdot 0)^{*}$ \\
\hline \multicolumn{6}{|l|}{$24 \mathrm{~h}(\mathrm{n}=9)$} \\
\hline Control & $62 \cdot 7(9 \cdot 2)$ & $58 \cdot 0(12 \cdot 0)$ & $16 \cdot 0(3 \cdot 1)$ & - & $4 \cdot 7(1 \cdot 2)$ \\
\hline SH1497 & $70 \cdot 7(7 \cdot 7)$ & $51 \cdot 8(10 \cdot 6)$ & $18 \cdot 3(5 \cdot 7)$ & - & $3.0(1.6)$ \\
\hline K454 & $64.8(8.4)$ & $64 \cdot 2(8 \cdot 3)$ & $22.7(6.0)$ & - & $3.3(1.9)$ \\
\hline
\end{tabular}

SEM shown in parentheses.

$* \mathrm{p}<0.05$ infected versus control.

Table II. Morphometric analysis of control explants and explants infected with test strains for $4 \mathrm{~h}$ or $24 \mathrm{~h}$

\begin{tabular}{|c|c|c|c|c|c|}
\hline $\begin{array}{l}\text { Explant } \\
\text { culture }\end{array}$ & $\begin{array}{l}\text { Projecting } \\
\text { cells }\end{array}$ & $\begin{array}{l}\text { Loss of } \\
\text { cilia from } \\
\text { ciliated } \\
\text { cells }\end{array}$ & $\begin{array}{l}\text { Cytoplasmic } \\
\text { blebbing }\end{array}$ & $\begin{array}{l}\text { Mitochondrial } \\
\text { abnormalities }\end{array}$ & $\begin{array}{c}\text { Mean } \\
\text { damage score }\end{array}$ \\
\hline \multicolumn{6}{|l|}{$4 h(n=7)$} \\
\hline Control & $1.22(0.07)$ & $1.44(0.37)$ & $1 \cdot 24(0 \cdot 12)$ & $1 \cdot 08(0 \cdot 1)$ & $1.25(0.13)$ \\
\hline SH 1497 & $1.32(0.12)$ & $1.19(0.06)$ & $1.35(0.07)$ & $1.31(0.14)$ & $1.29(0.08)$ \\
\hline K454 & $1.28(0.08)$ & $1.47(0.15)$ & $1.28(0.15)$ & $1.24(0.09)$ & $1.30(0.07)$ \\
\hline \multicolumn{6}{|l|}{$24 \mathrm{~h}(\mathrm{n}=9)$} \\
\hline Control & $1.11(0.02)$ & $1 \cdot 74(0 \cdot 26)$ & $1.05(0.33)$ & $1 \cdot 15(0.07)$ & $1.22(0.06)$ \\
\hline SH1497 & $2.29(0.29)^{*}$ & $2 \cdot 21(0 \cdot 40)$ & $2.13(0.27)^{*}$ & $2.39(0.28)^{*}$ & $2 \cdot 25(0.65)^{*}$ \\
\hline K454 & $2 \cdot 14(0 \cdot 28)$ & $1.96(0.31)^{*}$ & $2 \cdot 26(0.31)^{*}$ & $2.58(0.39)^{*}$ & $2 \cdot 24(0 \cdot 23)^{*}$ \\
\hline
\end{tabular}

SEM shown in parentheses.

$* \mathrm{p}<0.05$ infected versus control.

controls. When explants serially infected for $30 \mathrm{~min}$, $4 \mathrm{~h}, 14 \mathrm{~h}$ and $24 \mathrm{~h}$ were examined, TEM confirmed that damage to infected explants was progressive. Infected explants were indistinguishable from controls at $30 \mathrm{~min}$ after infection. When explants were examined $30 \mathrm{~min}, 4 \mathrm{~h}, 14 \mathrm{~h}$ and $24 \mathrm{~h}$ after infection by SEM, control tissue maintained normal morphology until $24 \mathrm{~h}$ when the surface epithelium appeared to be depleted of cilia. Infected explants demonstrated enhanced discharge of mucus from goblet cells at $4 \mathrm{~h}$ and $14 \mathrm{~h}$. By $24 \mathrm{~h}$, sections of the surface demonstrated stripping of epithelium down to basement membrane collagen with exfoliation of individual cells from epithelialised areas.

\section{$N$. meningitidis associated with the surface of non- ciliated epithelial cells}

By $4 \mathrm{~h}$ after infection, surface association was seen by TEM in four of seven explants infected with strain K454 with 7.50 (SEM 1.91)\% of epithelial cells and one of seven explants infected with strain SH1497, with $13 \%$ of available epithelial cells. These differences were not significant. After infection of explants for $24 \mathrm{~h}$, five of nine infected with strain K454, and seven of nine infected with strain $\mathrm{K} 454$, and seven of nine infected with strain SH1497 displayed association of meningococci with surface epithelial cells; strain K454 and strain SH1497 associated with 18 (SEM 7.44)\% and 5.88 (SEM 4.43 ) \% of surface epithelial cells respectively (not significant).

By TEM, the target cells were predominantly nonciliated. After infection for $4 \mathrm{~h}$, both strains associated with mucin-containing cells which formed the majority of the non-ciliated cell population (fig. 1; table I). Strain K454 formed large aggregates in association with such cells, and colonies extending well above the epithelial surface were formed. Such large aggregates of strain SH1497 were not observed. Serpinate microvillous projections from non-ciliated cells surrounded associating organisms (fig. 1). Association with nonmucin-containing non-ciliated cells was observed but was rare. By SEM, clusters of strain K454 were associated with discharging goblet cells after infection for $4 \mathrm{~h}$ (fig. 2). Surface association of strain SH1497 was seen relatively rarely by SEM; after $4 \mathrm{~h}$, no large clusters of organisms were observed. By $24 \mathrm{~h}$, association with surface epithelial cells was seen more consistently and occurred with all cell types, but after this period of infection there was a general increase in epithelial damage with large numbers of bacteria 


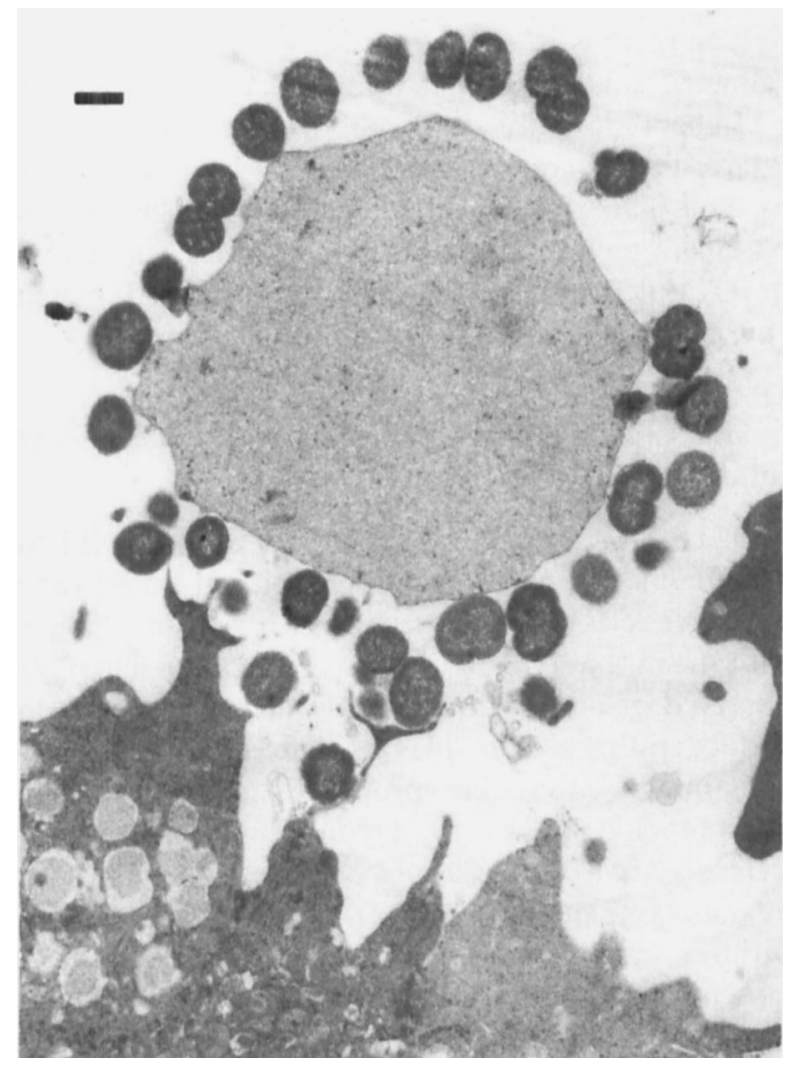

Fig. 1. Interaction of $N$. meningitidis with nasal turbinate explant epithelium after infection for $4 \mathrm{~h}$. TEM of strain K454 associating with a mucin-containing non-ciliated cell and surrounding a membrane-bound cytoplasmic bleb. Note serpiginous extensions from the cell appearing to surround the organism. (Bar $=0.4 \mu \mathrm{m})$.

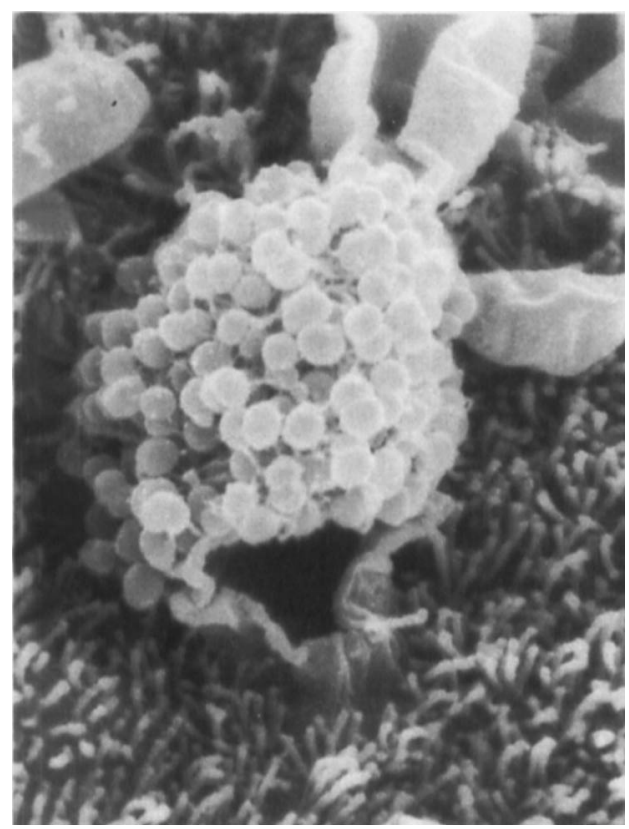

Fig. 2. SEM showing cluster of strain K454 associating with discharged goblet cells after infection for $4 \mathrm{~h}(\times 10000)$.

associating preferentially with damaged cells. Association of both strains with ciliated cells was rare.

Where bacteria were seen in association with ciliated cells, they were present either between, or near the tips

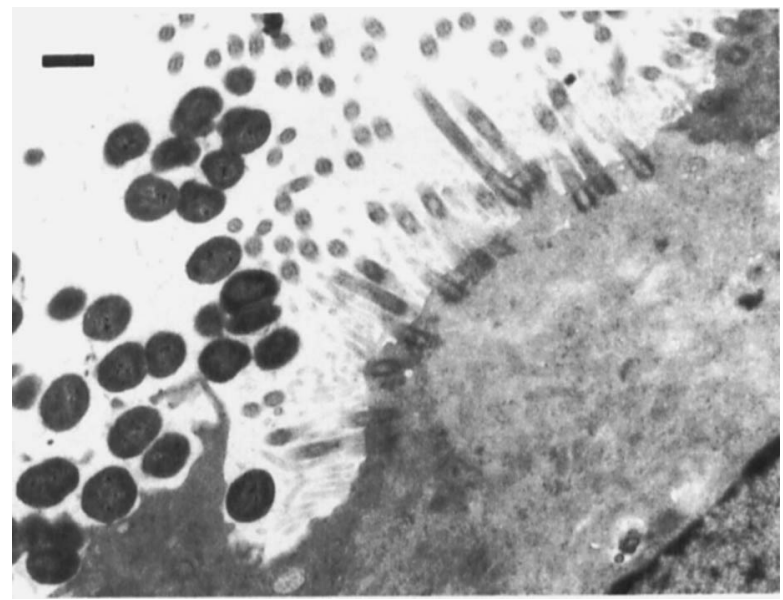

Fig. 3. Interaction of $N$. meningitidis with nasopharyngeal explant epithelium after infection for $24 \mathrm{~h}$. TEM of strain K454 associating with the ciliary tips of a ciliated epithelial cell, but in intimate association with an adjacent non-ciliated epithelial cell displaying "cupping" of the luminal surface near bacteria. $(\operatorname{Bar}=0.4 \mu \mathrm{m})$.

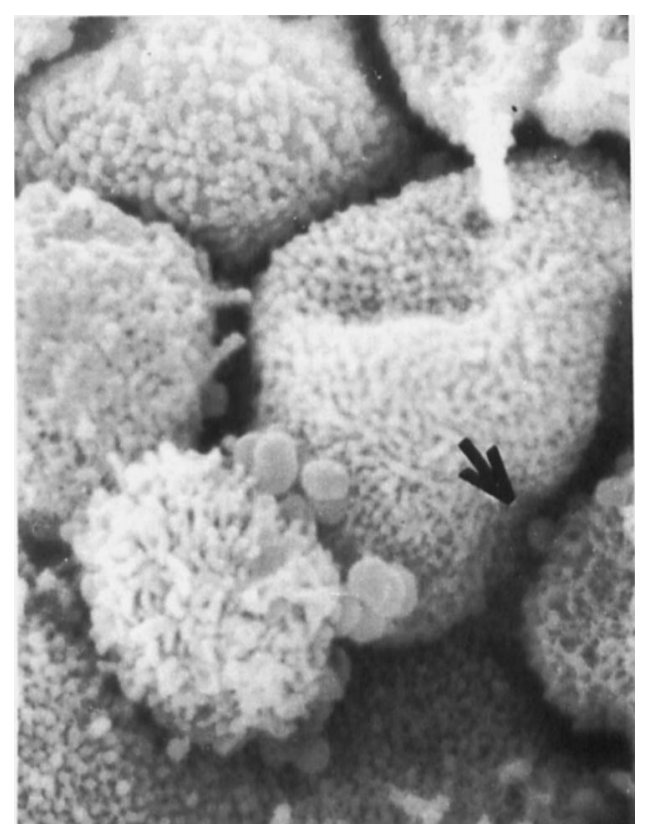

Fig. 4. Penetration of $N$. meningitidis (arrowed) between damaged epithelial cells after infection of nasopharyngeal explants for $24 \mathrm{~h}$. SEM demonstrating strain SH1497 between the loosened intercellular junctions of surface non-ciliated cells $(\times 25000)$.

of cilia; in contrast, association with non-ciliated cells was more intimate, with microvillous projections forming the "cupping" appearance of the surface of epithelial cells adjacent to bacteria (fig. 3). No differences were observed between the two strains in this host response. SEM demonstrated clustering of strains within damaged areas of epithelium. By SEM, large amounts of mucus were seen discharged on to the surface by $14 \mathrm{~h}$ of infection with both strains, but little bacterial adherence to mucus was observed in either case. Where epithelial cells were stripped away, no bacterial adherence to basement membrane collagen was seen. 


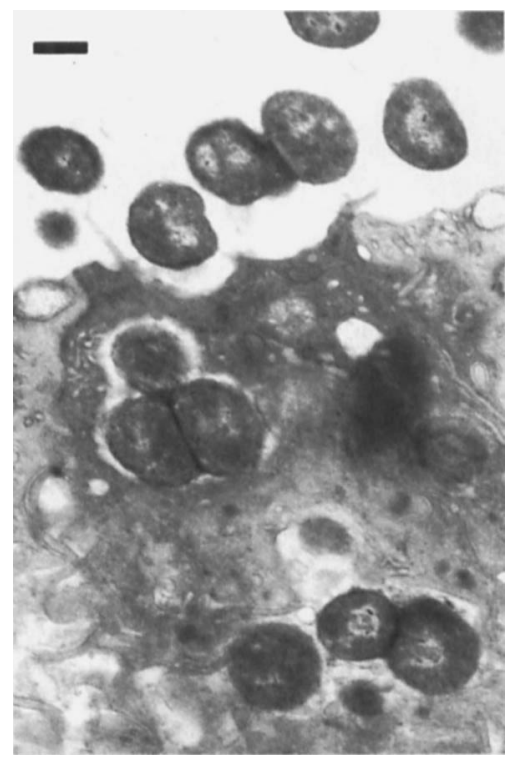

Fig. 5. SEM showing epithelial cell entry of strain K454 after infection for $24 \mathrm{~h}$, with "cupping" of a non-mucin-containing nonciliated cell and meningococci seen within membrane-bound vesicles. (Bar $=0.4 \mu \mathrm{m}$ ).

\section{Penetration of $N$. meningitidis between damaged surface epithelial cells}

By TEM, penetration of small numbers of bacteria between surface epithelial cells to associate with basal cells was observed in four of nine explants infected with strain $\mathrm{K} 454$ and three of nine explants infected with strain $\mathrm{SH} 1497$ for $24 \mathrm{~h}$, but this was observed only in regions of epithelium where there was marked cellular damage with extrusion of epithelial cells. By EM, bacteria were observed between the loosened intercellular junctions of surface non-ciliated cells (fig. 4). No organisms were identified within or beneath the basement membrane collagen by TEM, even in areas of high density association with disrupted surface epithelium.

\section{Internalisation of meningococci into membrane-bound vesicles of epithelial cells}

Of a total of 40 infected explants examined by TEM, the presence of bacteria internalised into membranebound vesicles was observed in only two, both infected with strain K454 for $24 \mathrm{~h}$. When this phenomenon was observed, it occurred in a small minority $(<5 \%)$ of surface epithelial cells, all non-ciliated and non-mucincontaining. Microvilli projected around surfacebound meningococci (fig. 5), and dividing organisms were seen within vesicles. A few cells appeared to tolerate large numbers $(>10)$ of meningococci (fig. 6) without apparent loss of integrity of the cell, or loosening of tight junctions. Such cells appeared devoid of surface microvilli. Organisms were observed deep within adjacent epithelial cells and there was evidence of migration to deep intercellular sites (fig. 7). Bacteria internalised by mononuclear phagocytes within the epithelial layer were observed in two

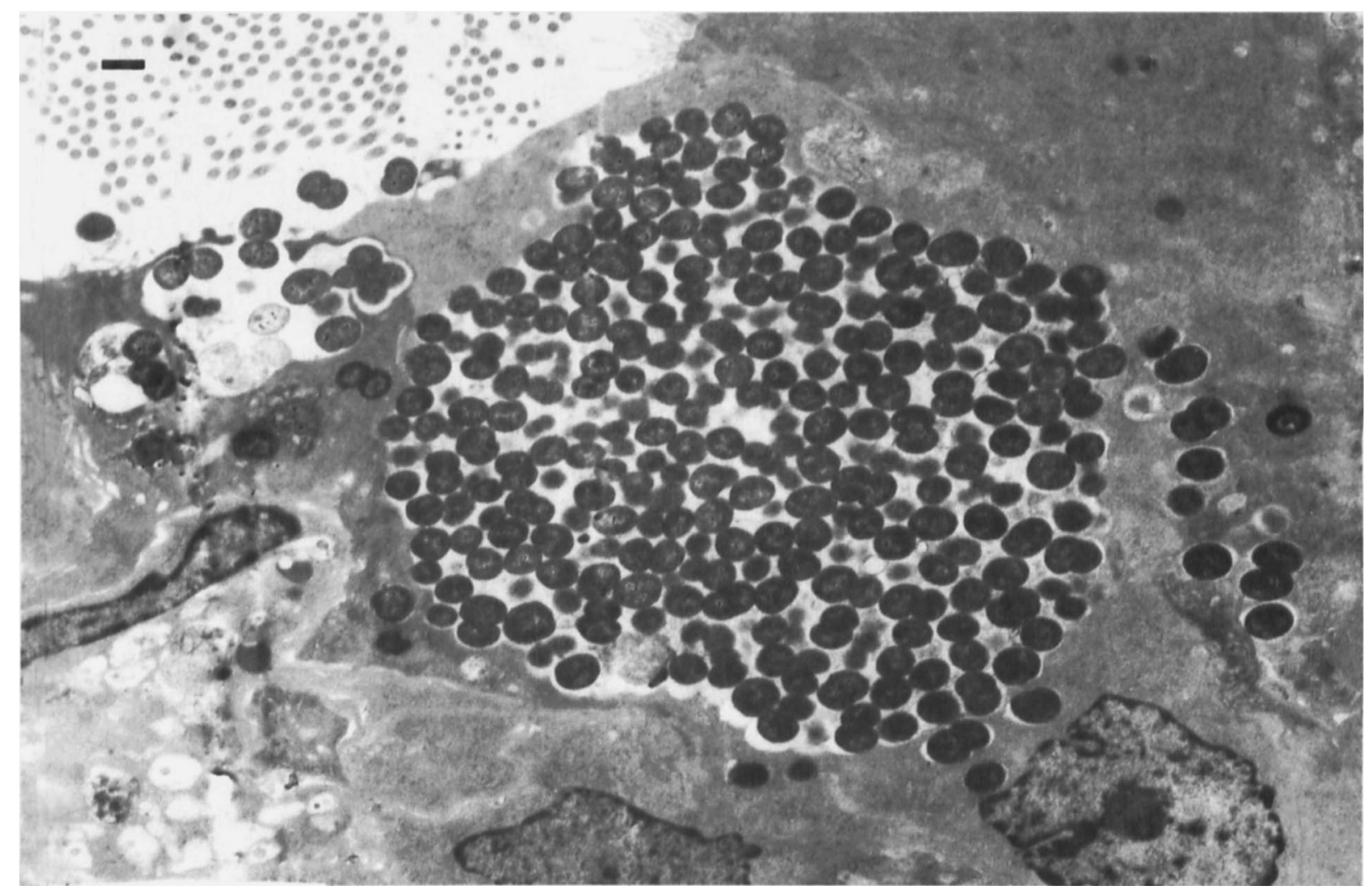

Fig. 6. TEM of nasal turbinate after infection with strain $\mathrm{K} 454$ for $24 \mathrm{~h}$ showing a large cluster of meningococci in what is probably an extracellular location with evidence of bacterial replication within large membrane-bound vesicles and migration into membrane-bound vesicles of adjacent cells. (Bar $=0.4 \mu \mathrm{m}$ ). 


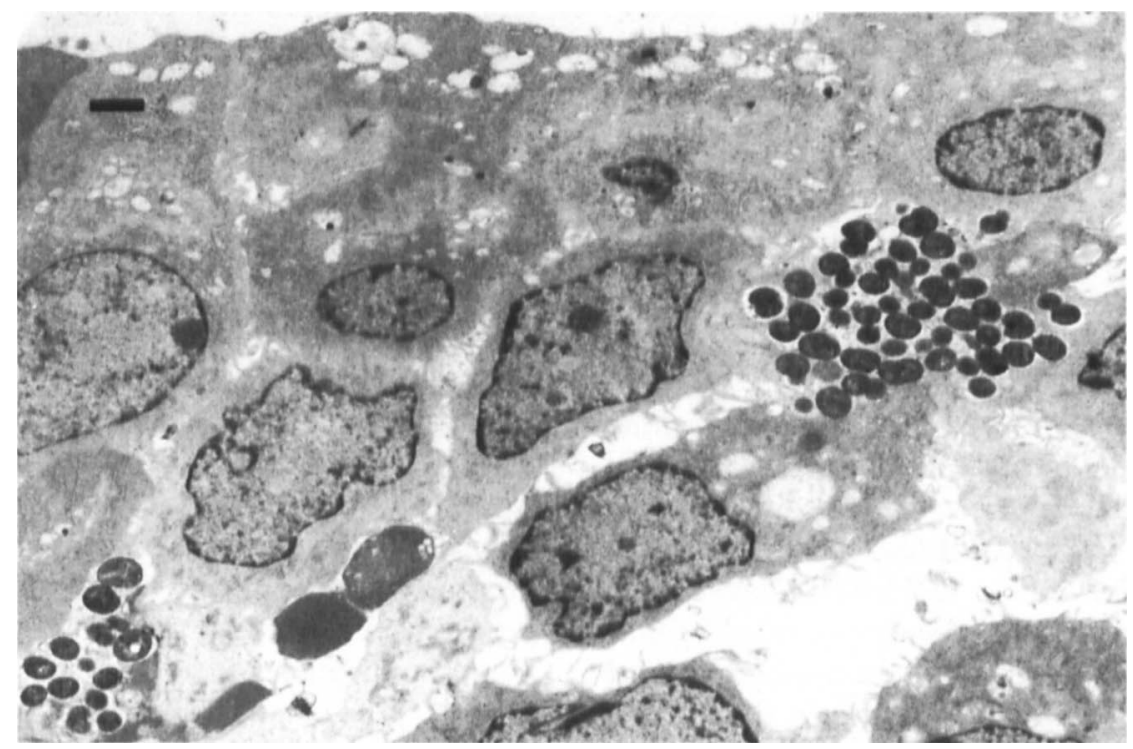

Fig. 7. In cells near to that shown in fig. 6, organisms are shown in deep intercellular locations with other organisms seen within cells nearby. (Bar $=0.6 \mu \mathrm{m})$.

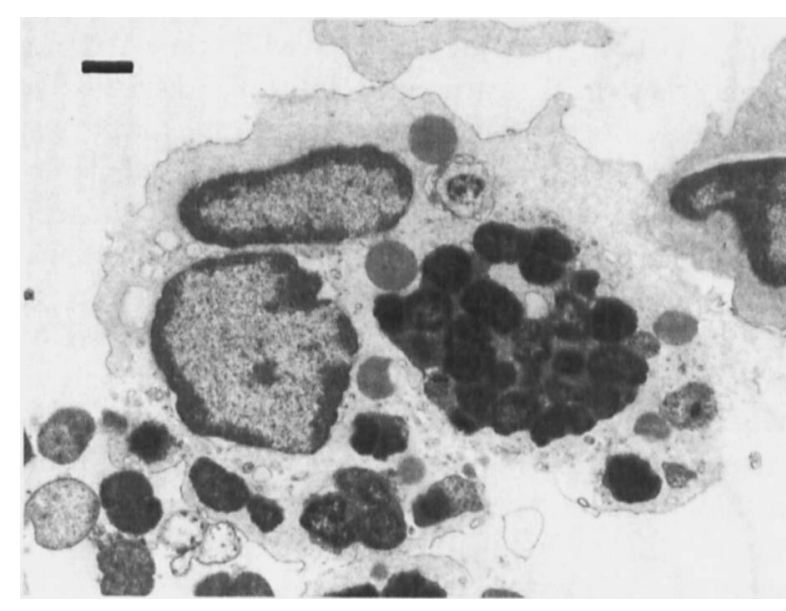

Fig. 8. TEM of explant infected with strain SH1497 for $24 \mathrm{~h}$ showing internalisation of meningococci by a mononuclear phagocyte. (Bar $=0.6 \mu \mathrm{m})$

explants infected for $24 \mathrm{~h}$ with strain $\mathrm{SH} 1497$ but this was not observed with strain K454 (fig. 8).

\section{Discussion}

For successful colonisation of the upper respiratory tract, the meningococcus requires a stable, nutritious environment. The rhinopharynx is a hostile environment; the majority of the mucosa is lined by pseudostratified ciliated columnar, mucus-secreting epithelium. Rapid ciliary beating discourages bacterial adherence by creating turbulence within periciliary fluid and propelling mucus to the oropharynx where it is swallowed or expectorated. Mucus contains antibacterial components including lysozyme, lactoferrin (which depletes available iron) and secretory immunoglobulin. Nonetheless, the meningococcus succeeds, and in-vitro studies such as this one have suggested that a number of factors may contribute to this.
Amongst these are the capacity to damage epithelial cells, to adhere to epithelial surfaces and to undergo parasite-directed endocytosis, ${ }^{8}$ a process which is unusual amongst pathogens that inhabit this site. Entry into host cells has been suggested as a prelude to invasion of the blood stream, but there is no direct evidence to support this view. Nevertheless, survival and replication within, and spread between host epithelial cells is likely to be a potent strategy in stable colonisation.

In the present study, naturally occurring, epidemiologically and phenotypically related strains were used to study the events that occur in experimental infection of nasal mucosa. Both isolates caused early change of epithelial cells from columnar to cuboidal morphology, and increased discharge of mucus from goblet cells. Considering the relative paucity of bacterial adherence after $4 \mathrm{~h}$ of infection, this observed cytotoxicity was presumably initiated by release of host or bacterial products into the supernate. As infection progressed, there was further damage to the epithelium, including exfoliation of cells, cytoplasmic blebbing and mitochondrial abnormalities. This was observed with both ciliated and non-ciliated cells, and has been described previously in adenoid organ culture. ${ }^{5}$ Gonococci also damage ciliated cells of the human fallopian tube: ${ }^{16}$ gonococcal lipopolysaccharide is at least partly responsible for this cytotoxicity. ${ }^{17}$ However, purified meningococcal lipopolysaccharide does not apparently damage structure or function of human respiratory ciliated cells, ${ }^{5}$ although it does damage fallopian tube mucosa. Loss of capsule by Haemophilus influenzae type b results in a significant reduction in damage to nasopharyngeal mucosa ${ }^{18}$ but the present study suggests that the absence of a capsule in naturally occurring meningococci does not result in decreased cytotoxicity in a similar organ culture system. The only meningococcal virulence determinant which has been shown to correlate with the 
degree of cytotoxicity is piliation; the rate of damage to human adenoid organ cultures is greater with piliate than non-piliate capsulate meningococci. ${ }^{5}$ Both strains in this study caused an increase in discharge of mucus from goblet cells by $4 \mathrm{~h}$ after infection. This may be a non-specific response by the host, as various respiratory pathogens have been shown to cause increased mucus discharge from mammalian respiratory tract. ${ }^{19}$

Quantification of bacterial association with the surface of explants showed that $N$. meningitidis associated with a minority of epithelial cells - most frequently non-ciliated. There was no difference between the two strains used in these experiments. This contrasts with previously published data. With genetically modified strains, Stephens et $a l^{9}{ }^{9}$ found that a mutant non-capsulate strain associated more frequently with human adenoid mucosa than did its fully capsulate parent, but only after infection for $6 \mathrm{~h}$ (not after 12 or $24 \mathrm{~h}$ ). The increase in adherence was only 1.3-6.5-fold; by comparison the effect of loss of capsule by $H$. influenzae type $\mathrm{b}$ is much greater ${ }^{18,20}$

In the present study, the majority of non-ciliated cells contained mucinous material, and meningococci associated with them after infection for $4 \mathrm{~h}$, suggesting that non-ciliated mucin-containing cells may be an initial site of attachment for meningococci in this tissue. Paradoxically, association with secreted mucus was seen with neither strain. This is in marked contrast to the proclivity of non-typable $H$. influenzae strains for adherence to mucus. ${ }^{10}$ By TEM, dense clusters of capsulate organisms extended above the epithelium during the early stage $(4 \mathrm{~h})$ of infection. The appearance of capsulate organisms within an extracellular gel-like material has been noted both with $H$. influenzae type $\mathrm{b}^{18}$ and with Streptococcus pneumoniae $^{21}$ in this model. Such an extracellular matrix might afford the formation of large microcolonies without the requirement for epithelial adherence to protect individual organisms from host defences. Other organisms appear to behave similarly during respiratory tract colonisation; Pseudomonas aeruginosa is found within dense fibre-enclosed packages of exopolysaccharide in post-mortem studies of patients with cystic fibrosis. ${ }^{22}$

In the present study penetration of the apical junctions of epithelial cells by meningococci and association with basal cells observed, apparently in the absence of endocytosis, though this occurred only where disruption of surface epithelial cells was evident. In previous descriptions with adenoid tissue, ${ }^{7,8}$ endocytosis by surface epithelial cells was the predominant mechanism of epithelial entry. The ability of meningococci to penetrate between disrupted epithelial cells is probably irrelevant to stable colonisation of the normal nasopharynx, but might be more important where there is coincident epithelial damage, e.g. by virus or environmental pollutants. There is a noted association between meningococcal disease and recent virus infection ${ }^{23}$ and also a correlation between meningococcal carriage and active and passive smoking. ${ }^{3}$ Again, in contrast to studies with adenoid tissue, penetration within or beneath the basement membrane collagen was not observed in the present study, which suggests either that non-lymphoid nasal mucosa may be a site of stable colonisation for meningococci (but not a potential source of bloodstream invasion) or that penetration of basement membrane collagen is not the mechanism of bloodstream invasion.

Endocytosis of the capsulate strain was demonstrated, but this was a rare event, occurring in a small proportion of explants, suggesting either that the permissive host cell is rare within the tissue used, or that the phenomenon is host dependent. Cells that tolerate large numbers of dividing meningococci may represent a bridge-head for prolonged colonisation of the nose. The appearance of organisms within adjacent cells suggests that meningococci may be able to further persist by lateral intercellular migration. Although some of these cells lacked microvilli, they did not display the other features of intestinal $\mathbf{M}$ cells; in particular, no adjacent lymphocytic infiltration was observed, and although cells with endocytosed meningococci were occasionally observed above the epithelium, no migration to the subepithelial space was seen, providing evidence against their role as specialised antigen-presenting cells. Phagocytosis by mononuclear phagocytes was observed, but only in two of the explants infected for $24 \mathrm{~h}$ by the noncapsulate strain. This does represent a potential route of bloodstream spread, as mononuclear cells are capable of trafficking between epithelium and the richly vascularised subepithelial tissues.

In summary, a number of mechanisms by which meningococci might achieve stable colonisation of ciliated human nasal mucosa have been demonstrated. These include toxic damage, adherence to surface cells and penetration between cells of damaged epithelium. The presence of a capsule did not determine these processes. Further potential mechanisms, for which the presence of a capsule may be necessary, include the formation of large aggregates of surface-associated organisms and the propensity to replicate within a minority of non-ciliated cells. Penetration of the basement membrane collagen was not observed, but phagocytosis by mononuclear cells was seen, which may represent a mechanism of bloodstream invasion from this site.

We are grateful to Dr R. Wilson for his valuable comments, to Dr R. Dixon for statistical advice, and to Janet Hanson for her help with preparation of the manuscript. This study was supported by a Trent Regional Health Authority Research Committee Award. We are grateful to Eli Lilly for financial assistance. 


\section{References}

1. Aycock WL, Mueller JH. Meningococcus carrier rates and meningitis incidence. Bacteriol Rev 1950; 14: 115-160.

2. Broome CV. The carrier state: Neisseria meningitidis. $J$ Antimicrob Chemother 1986; 18 Suppl: 25-34.

3. Caugant DA, Høiby EA, Magnus $P$ et al. Asymptomatic carriage of Neisseria meningitidis in a randomly sampled population. J Clin Microbiol 1994; 32: 323-330.

4. Olcen P, Kjellander J, Danielsson D, Lindquist BL. Culture diagnosis of meningococcal carriers: yield from different sites and influence of storage in transport medium. J Clin Pathol 1979; 32: 1222-1225.

5. Stephens DS, Whitney AM, Melly MA, Hoffman LH, Farley MM, Frasch CE. Analysis of damage to human ciliated nasopharyngeal epithelium by Neisseria meningitidis. Infect Immun 1986; 51: 579-585.

6. Virji M, Makepeace K, Ferguson DJP, Achtman M, Sarkari J, Moxon ER. Expression of the Opc protein correlates with invasion of epithelial and endothelial cells by Neisseria meningitidis. Mol Microbiol 1992; 6: 2785-2795.

7. Stephens DS, Hoffman LH, McGee ZA. Interaction of Neisseria meningitidis with human nasopharyngeal mucosa: attachment and entry into columnar epithelial cells. $J$ Infect $D i$ is 1983; 148: 369-376.

8. Stephens DS, Farley MM. Pathogenic events during infection of the human nasopharynx with Neisseria meningitidis and Haemophilus influenzae. Rev Infect Dis 1991; 13: 22-33.

9. Stephens DS, Spellman PA, Swartley JS. Effect of the $(\alpha 2 \rightarrow 8)$ linked polysialic acid capsule on adherence of Neisseria meningitidis to human mucosal cells. J Infect Dis 1993; 167 : 475-479.

10. Read RC, Wilson R, Rutman A et al. Interaction of nontypable Haemophilus influenzae with human respiratory mucosa in vitro. J Infect Dis 1991; 163: 549-558.

11. Sorokin S. The respiratory system. In: Weiss L (ed) Cell and tissue biology: a textbook of histology, 6th edn. Baltimore, Urban and Schwarzenberg. 1988: 753-813.

12. Mackinnon FG, Borrow R, Gorringe AR, Fox AJ, Jones DM, Robinson A. Demonstration of lipooligosaccharide immunotype and capsule as virulence factors for Neisseria meningitidis using an infant mouse intranasal infection model. Micro Pathog 1993; 15: 359-366.

13. Cartwright KAV, Stuart JM, Jones DM, Noah ND. The Stonehouse survey: nasopharyngeal carriage of meningococci and Neisseria lactamica. Epidemiol Infect 1987;99: $591-601$.

14. Jones DM, Borrow R, Fox AJ, Gray S, Cartwright KAV, Poolman JT. The lipooligosaccharide immunotype as a virulence determinant in Neisseria meningitidis. Microb Pathog 1992; 13: 219-224.

15. Abdillahi H, Poolman JT. Whole-cell ELISA for typing Neisseria meningitidis with monoclonal antibodies. FEMS Microbiol Lett 1987; 48: 367-371.

16. McGee ZA, Johnson AP, Taylor-Robertson D. Pathogenic mechanisms of Neisseriae gonorrhoeae: observations on damage to human fallopian tubes in organ culture by gonococci of colony type 1 or type 4 . J Infect Dis 1981; 143: 413-422.

17. Cooper MD, McGraw PA, Melly MA. Localization of gonococcal lipopolysaccharide and its relationship to toxic damage in human fallopian tube mucosa. Infect Immun $1986 ; 51: 425-430$.

18. Read RC, Rutman AA, Jeffery PK et al. Interaction of capsulate Haemophilus influenzae with human airway mucosa in vitro. Infect Immun 1992; 60: 3244-3252.

19. Adler KB, Hendley DD, Davis GS. Bacteria associated with obstructive pulmonary disease elaborate extracellular products that stimulate mucin secretion by explants of guinea pig airways. Am J Pathol 1986; 125: 501-514.

20. St Geme, JW, Falkow S. Loss of capsule expression by Haemophilus influenzae type $\mathrm{b}$ results in enhanced adherence to and invasion of human cells. Infect Immun 1991; 59: 1325-1333.

21. Feldman C, Read RC, Rutman et al. The interaction of Streptococcus pneumoniae with intact human respiratory mucosa in vitro. Eur Respir J 1992; 5: 576-583.

22. Lam J, Chan R, Lam K, Costerton JW. Production of mucoid microcolonies by Pseudomonas aeruginosa within infected lungs in cystic fibrosis. Infect Immun 1980; 28: 546-556.

23. Moore PS, Heirholzer J, Dewitt W et al. Respiratory viruses and Mycoplasma as cofactors for epidemic Group A meningococcal meningitis. JAMA 1990; 264: 1271-1275. 